\title{
Development Issues of Social Parameters of Population Life in Discomfort Northern Territories of Russia (Exemplified by the Republic of Sakha (Yakutia))
}

\author{
Leonid M. Korytny, Lyudmila B. Bashalkhanova, Viktoria N. Veselova, \\ Innokentiy A. Bashalkhanov
}

V.B. Sochava Institute of Geography SB RAS (IG SB RAS), Irkutsk, Russia

Email: kor@irigs.irk.ru, ldm@irigs.irk.ru, veselova@irigs.irk.ru

How to cite this paper: Korytny, L.M., Bashalkhanova, L.B., Veselova, V.N. and Bashalkhanov, I.A. (2017) Development Issues of Social Parameters of Population Life in Discomfort Northern Territories of Russia (Exemplified by the Republic of Sakha (Yakutia)). Open Access Library Journal, 4: e3677.

https://doi.org/10.4236/oalib.1103677

Received: May 17, 2017

Accepted: June 19, 2017

Published: June 22, 2017

Copyright $\odot 2017$ by authors and Open Access Library Inc.

This work is licensed under the Creative

Commons Attribution International

License (CC BY 4.0).

http://creativecommons.org/licenses/by/4.0/

\begin{abstract}
The paper considers the transformation of social guarantees by the example of statutory subsistence minimum in the Republic of Sakha (Yakutia). It was revealed that the rate of decline subsistence minimum compared to climatically the less severe territories contributed to the aggravation of problems of social security. The structure of dynamics of the purchasing power of the population's wages, both at the level of municipalities and for the main economic activities, shows social vulnerability of a person with the increase in climate discomfort that causes a decline in living standards and an increase in the migration mobility of the population.
\end{abstract}

\section{Subject Areas}

Sociology

\section{Keywords}

Social Protection, Subsistence Minimum, Living Standard, Climate Discomfort

\section{Introduction}

In Russia, the natural-climatic discomfort of the northern territories constitutes one of the major limiting factors of their large-scale development, and requires adequate sustenance. The inconformity of the social protection system with the spatial-temporal changes in the quality of the environment often deprives the population of regions with severe natural-climatic conditions of living condi- 
tions equal to those of residents of other areas, and leads to the occurrence of hotbeds of socio-economic disparities and tension. As noted by A.Yu. Shevyakov [1] disparities in the social sphere are expressed in the excessive economic inequality of incomes and poverty of the population. One of the examples is the Republic of Sakha (Yakutia) located in the north-east of the Eurasian continent.

The territory of the Republic is characterized by a long period of heating season (from 8.5 to 12 months), ultraviolet starvation (from 3.6 months in the south of the region up to 6 months in the north), violation of the light regime change (up to 5 - 6 months in the north), sharp weather-climatic contrasts, and low air temperatures combined with frequent repetition of high wind speeds in some locations. Joint action of the abovementioned events often forms the weather, dangerous for a long stay outdoors. According to the degree of cumulative impacts of climatic parameters on the territory of the Republic of Sakha (Yakutia), we have distinguished three levels of discomfort: very strong, severe and extremely severe (Figure 1).

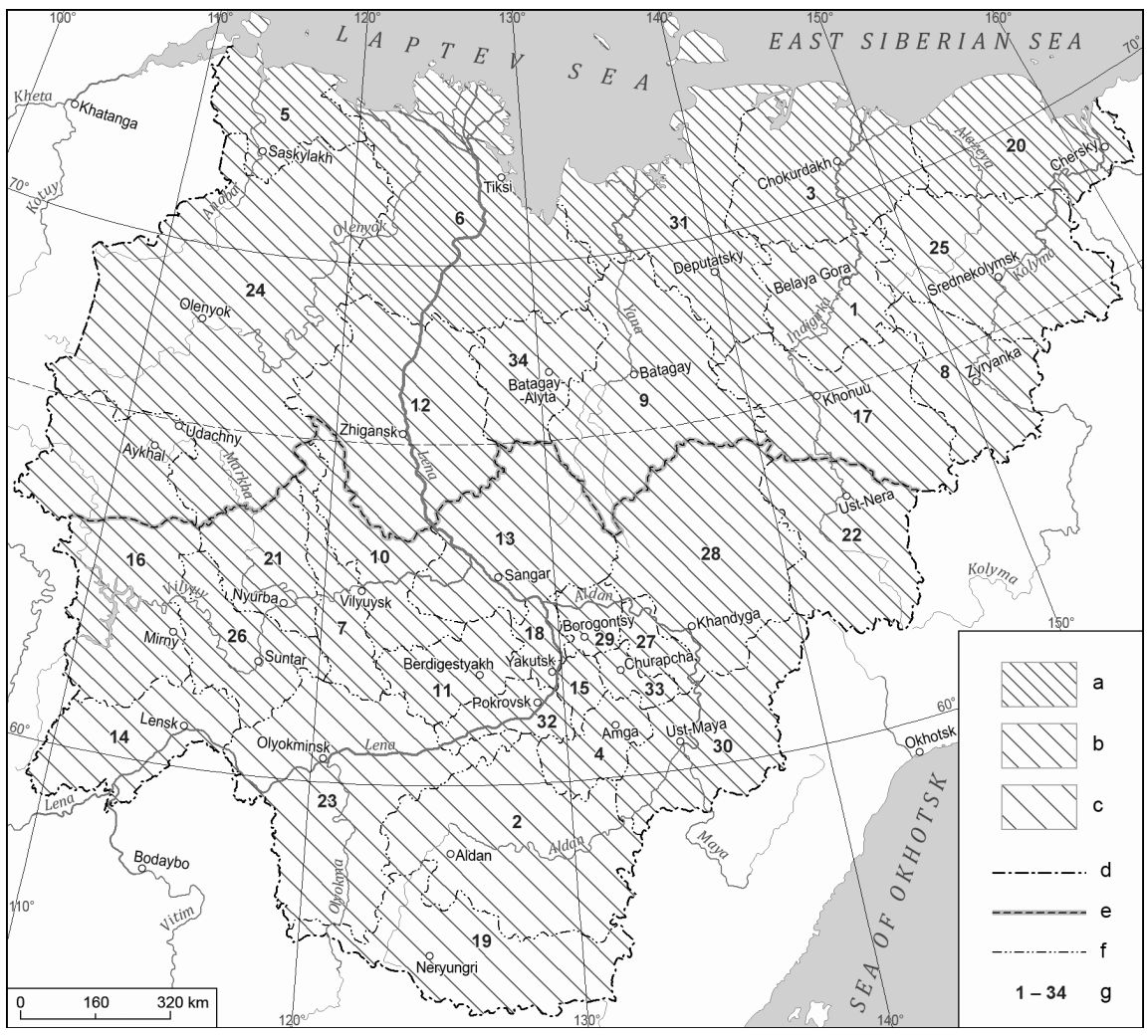

Figure 1. Natural climatic conditions of the Sakha (Yakutia) Republic. Note. The level of discomfort: a-extremely severe, b-severe, c-very strong. Boundaries of: d-subjects, e-statutory SM, f-municipal districts. Municipal districts: g 1-Abyysky; 2-Aldansky; 3-Allaikhovsky; 4-Amginsky; 5-Anabarsky; 6-Bulunsky; 7-Verkhnevilyuysky; 8-Verkhnekolymsky; 9-Verkhoyansky; 10-Vilyuysky; 11-Gorny; 12-Zhigansky; 13-Kobyaysky; 14 Lensky; 15-Megino-Kangalassky; 16-Mirninsky; 17-Momsky; 18-Namsky; 19-Neryungrinsky; 20-Nizhnekolymsky; 21-Nyurbinsky; 22-Oymyakonsky; 23-Olyokminsky; 24Olenyoksky; 25-Srednekolymsky; 26-Suntarsky; 27-Tattinsky; 28-Tomponsky; 29-UstAldansky; 30-Ust-Maysky; 31-Ust-Yansky; 32-Khangalassky; 33-Churapchinsky; 34Eveno-Bytantaysky National. 
As on 01.01.2016, 959.7 thousand people lived in the Republic [2]. The major portion of the population is concentrated in cities and industrial centers, located in the conditions of severe (78.6\% of the population) and very strong $(18.7 \%)$ discomfort. Significantly smaller number of people (only $2.7 \%$ of the population) lives in five municipal districts occupying $19 \%$ of the total area of the Republic with extremely severe climate. As compared with 1994, the population of the Republic decreased by a factor of 1.1, moreover, in areas of extremely severe discomfort it became twice as little.

Unfortunately, the quality of life of the majority of this population is noticeably inferior to the average Russian standards, not to mention the world standards, and the issues concerning its improvement are particularly relevant. In consequence of a huge diversity of natural and social factors, interacting over a vast area, the municipal districts vary widely in their capabilities to ensure decent living conditions of the population. The state policy strategy is aimed at a consistent rise in the living standards of the population, namely: improvement of the demographic situation, poverty reduction, and ensuring decent living conditions. However, the trend in the quality of life of the population of the Republic of Sakha (Yakutia) provides evidence of infringement of their rights to satisfactory living conditions, taking into account the opportunities (or limitations) of the environment [3]. The study of the geographical features of the area and the analysis of the interrelations of resource and social factors and characteristics make it possible to reveal the hotbeds of socio-economic disparities and identify the ways to improve the life quality of the population of the discomfort territories.

\section{Transformation of Social Guarantees in the Northern Regions}

Climate severity of has a significant impact on all aspects of life of the population, accordingly, the basic parameters of ensuring physiological comfort of human life and activities are of paramount importance. Under the conditions of fixed prices for goods and services in the planned economy, the role of social protection of the population was fulfilled by the division of the regions into the regions of the Far North and equivalent areas with intra-regional differentiation of coefficients, allowances and related benefits. At the present stage the role of such protection is fulfilled by the Federal Law "On the Subsistence Minimum in the Russian Federation" [4], which aims to preserve health and equal support of human life and activities throughout the country. In every federal subject, the regional authorities adjust the statutory subsistence minimum (SM) in accordance with the features of a territory and trends in price balancing [5].

However, the analysis has revealed a significant lag of growth rate of SM values in the Republic of Sakha (Yakutia) as compared with climatically favorable areas (Table 1), although it is in the severe natural-climatic conditions where the costs of life necessities, such as food, clothing, housing and utilities and other services, are higher. 
Table 1. Statutory subsistence minimum in the subjects of the Russian Federation (RF) [6]-[11].

\begin{tabular}{cccc}
\hline \multirow{2}{*}{ Subjects of the RF } & \multicolumn{3}{c}{ Subsistence level } \\
\cline { 2 - 4 } & 1994, RUB & $4^{\text {th }}$ quarter of 2015, RUB & $\begin{array}{c}2015 / 1994, \\
\text { exceedance }\end{array}$ \\
\hline Moscow Oblast & 82.0 & 10,460 & 127.6 \\
Sakha (Yakutia) Republic & 205.8 & 15,515 & 75.4 \\
Irkutsk Oblast & 102.4 & 9814 & 95.8 \\
Krasnoyarsk Krai & 88.4 & 10,598 & 119.9 \\
Republic of Buryatia & 99.7 & 9259 & 92.9 \\
\hline
\end{tabular}

The intra-regional differentiation has also undergone significant changes. Till the $3^{\text {rd }}$ quarter of 2002 the SM was calculated for 6 territories, with the difference in space of 1.6 times. Even so, the territorial differentiation was insufficient to reflect the degree of climate discomfort (Table 2): areas, sharply contrasting in terms of the climate severity, had the same level of the SM (Mirninsky, Lensky, etc.), or vice versa, under the same conditions of climate severity the SM level could be 1.5 times different. Since the $3^{\text {th }}$ quarter of 2002 the SM has been calculated for two zones; the difference of the SM has decreased significantly and began to average 1.1 times, i.e. the natural-climatic differences of Arctic and central districts are almost not taken into consideration. Starting from 2013, as a result of the amendments to the assessment of the SM, the difference between the two zones has increased up to 1.2 times (see Table 2).

\section{Real Incomes of the Population}

Low values of the statutory SM lead to an underestimation of other social guarantees (minimum wage, pensions, benefits, etc.), but at the same time give a rather satisfactory image to the purchasing capacity of wages (PCW). The spatial-temporal analysis of the dynamics of this indicator dramatically reflects the fluctuations of the intra-regional differentiation of calculating the SM (Figure 2). The financial and economic crisis of 1998 caused a countrywide intense deterioration of the socio-economic situation of the population in 1999-2000. Minimum values (less than 1.5 times) began to dominate in the structure of the PCW in $89 \%-100 \%$ of districts with severe and extremely severe discomfort.

At the end of 2002, as a consequence of the change in the intra-regional differentiation of calculating the subsistence minimum, an abrupt increase in the dynamics of the territorial structure of the PCW took place (see Figure 2). The actual socio-economic situation of the population did not change because of this "game of figures", but according to statistics the situation improved markedly. Even the 2008 crisis did not affect negatively the PCW structure.

Thus, under the conditions of extremely severe discomfort $20 \%$ of the districts started to have the PCW of more than 3.0 times, while the remaining $80 \%$ from 2 to 2.5 times. Corrective amendments in 2013 affected the increase in quantities of PCW of 2013-2015. The situation has changed significantly also under the 
Table 2. Intra-regional differentiation of the subsistence minimum.

\begin{tabular}{|c|c|c|c|c|c|c|}
\hline \multirow{3}{*}{$\begin{array}{l}\text { Level of } \\
\text { climate } \\
\text { discomfort }\end{array}$} & \multicolumn{3}{|c|}{$\begin{array}{l}\text { Intra-regional differentiation of the SM } \\
\text { till the } 3^{\text {rd }} \text { quarter of } 2002\end{array}$} & \multicolumn{3}{|c|}{$\begin{array}{l}\text { Intra-regional differentiation of the } \\
\text { SM after the } 3^{\text {rd }} \text { quarter of } 2002\end{array}$} \\
\hline & & & SM of the & & SM of the & SM of the \\
\hline & Municipal districts & Zones & $\begin{array}{c}4^{\text {th }} \text { quarter of } \\
1994, \text { RUB }\end{array}$ & Zones & $\begin{array}{l}4^{\text {th }} \text { quarter of } \\
2003, \text { RUB }\end{array}$ & $\begin{array}{l}4^{\text {th }} \text { quarter of } \\
2015, \text { RUB }\end{array}$ \\
\hline \multirow{4}{*}{ Very strong } & Olyokminsky & 1 & 228,525 & & & \\
\hline & Neryungrinsky & 4 & 216,811 & & & \\
\hline & Aldansky & & 40,01 & & & \\
\hline & Lensky & & & & & \\
\hline \multirow{27}{*}{ Severe } & Mirninsky & ( & 2 & & & \\
\hline & Yakutsk town district & 5 & 314,287 & & & \\
\hline & Amginsky & & & & & \\
\hline & Gorny & & & & & \\
\hline & Megino-Kangalassky & & & & & \\
\hline & Namsky & 1 & 228525 & & & \\
\hline & Tattinsky & & 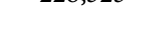 & II & 3606 & 15,223 \\
\hline & Ust-Aldansky & & & & & \\
\hline & Khangalassky & & & & & \\
\hline & Churapchinsky & & & & & \\
\hline & Vilyuysky & & & & & \\
\hline & Nyurbinsky & & & & & \\
\hline & Suntarsky & 3 & 279,503 & & & \\
\hline & Verkhnevilyuysky & & & & & \\
\hline & Ust-Maysky & & & & & \\
\hline & Tomponsky & & & & & \\
\hline & Kobyaysky & & & & & \\
\hline & Abyysky & & & & & \\
\hline & Verkhnekolymsky & & & & & \\
\hline & Verkhoyansky & & & & & \\
\hline & Zhigansky & & & & & \\
\hline & Momsky & & & & & \\
\hline & Oymyakonsky & & & & & \\
\hline & Olenyoksky & 2 & 348,122 & & & \\
\hline & Srednekolymsky & & & I & 4080 & 17,924 \\
\hline & Eveno-Bytantaysky & & & & & \\
\hline & National & & & & & \\
\hline \multirow{5}{*}{$\begin{array}{l}\text { Extremely } \\
\text { severe }\end{array}$} & Allaikhovsky & & & & & \\
\hline & Anabarsky & & & & & \\
\hline & Bulunsky & & & & & \\
\hline & Nizhnekolymsky & & & & & \\
\hline & Ust-Yansky & & & & & \\
\hline
\end{tabular}

Note: ${ }^{\star}$ Mirninsky district belongs to the zone 2 except for the settlement of Aykhal with inhabited localities and the town of Udachny with inhabited localities. 


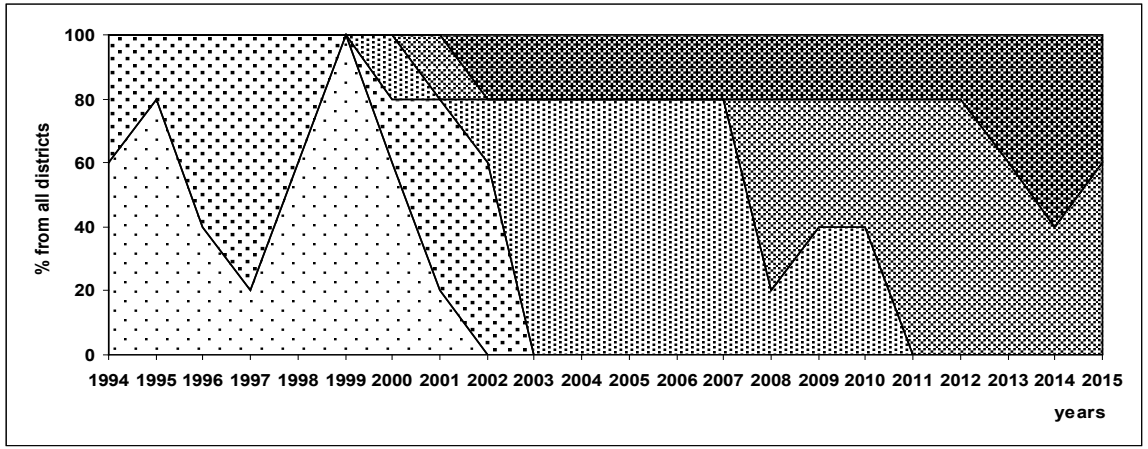

(a)

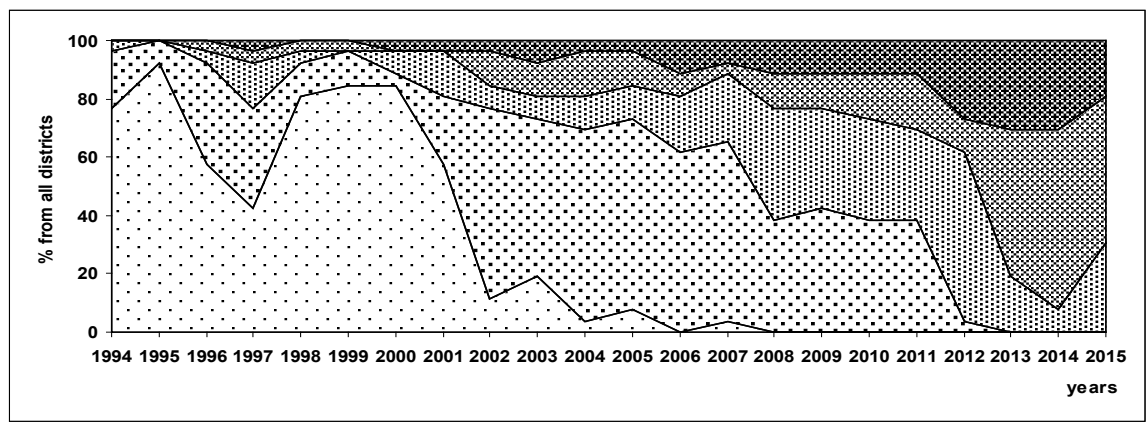

(b)

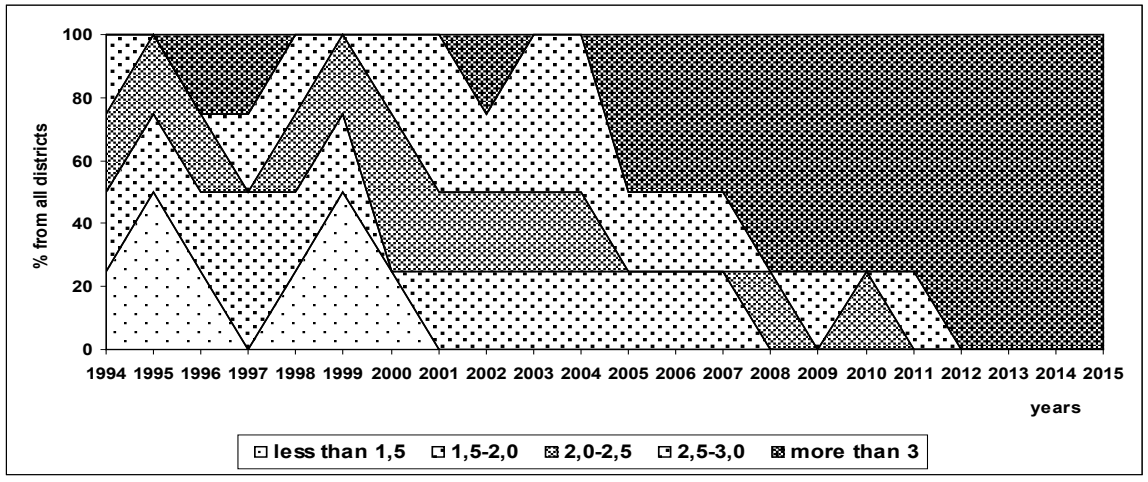

(c)

Figure 2. The structure of the purchasing capacity of wages under the conditions of extremely severe (a); severe (b); and very strong (c) discomfort. Source: [2] [12] [13].

conditions of severe discomfort: the prevalence of low (less than 1.5 times) values of the PCW has been replaced by stable values of more than 1.5 times. The number of districts with the PCW from 1.5 to 2.5 times varies from $65 \%-80 \%$ till 2008, with a gradual decrease in the number of districts with the PCW values amounting to up to 2 times. By 2015 the number of districts with the PCW of up to 2.5 times has accounted for about $30 \%$. The leaders of the high PCW values (more than 3.0 times) are Mirninsky and Oymyakonsky districts, the Yakutsk town district and, in recent years Nyurbinsky and Olenyoksky districts.

In the southern districts of the Republic, in a very strong climate discomfort, more than $75 \%$ of the districts started to have the PCW of up to 3.0 times by 2005. The most consistently high PCW value (more than 3.0) is registered in the Neryungrinsky district, while the Olyokminsky district has a consistently low 
value (less than 2.0 till 2008). By 2015, the PCW became to amount to more than 3 times in all districts.

However, it is known that a high intra-regional differentiation of wages takes place according to the sectors of economy. Territories with large industrial enterprises, where wages are much higher, contribute to the relatively favorable averages. According to data of the Federal State Statistics Service of the Russian Federation, in 2015 [14] the average nominal monthly wage paid amounted to 54,631 RUB and 34,030 RUB in the Republic of Sakha (Yakutia) and in the Russian Federation, respectively. The well-paid economic activities are extraction of commercial minerals, Building industry, financial activities, public administration and defense, and social insurance (Table 3 ). Excess of wages in these activities ranges from 1.1 to 1.6 times of the mean value for the subject.

The most low-paid activities are agriculture, hunting and forest management; provision of other communal, social and personal services; wholesale and retail trade, repair and manufacturing. The share of wages in these sectors ranges from $455 \%$ to $69 \%$ of the average wage in the subject. In other types of economic activity (education, health care, etc.), this share varies from $75 \%$ to $94 \%$.

The raise in wages with the increase in climate discomfort is traced only in certain types of economic activity. Moreover, the socio-economic status of the population is exacerbated by the fact that in the structure of their money income the largest percent is accounted for by the labor expense: $41.6 \%$, in Russia, and $59.2 \%$ in the Republic of Sakha (Yakutia) [14].

Table 3. Comparative assessment of the average monthly wage in the Republic of Sakha (Yakutia) under the conditions of different levels of climate discomfort, 2015 [2].

\begin{tabular}{|c|c|c|c|}
\hline \multirow{3}{*}{ Types of economic activity } & \multicolumn{3}{|c|}{ Average monthly wage paid, RUB } \\
\hline & \multicolumn{3}{|c|}{ Level of climate discomfort } \\
\hline & 1 & 2 & 3 \\
\hline Agriculture, hunting and forest management & 28,153 & 25,146 & 17,119 \\
\hline Extraction of commercial minerals & 75,532 & 93,984 & - \\
\hline Manufacturing & 42,248 & 36,236 & 43,407 \\
\hline $\begin{array}{l}\text { Generation and distribution of electric power, } \\
\text { gas and water }\end{array}$ & 52,021 & 39,801 & 49,565 \\
\hline Building industry & 61,045 & 60,671 & - \\
\hline Wholesale and retail trade, repair, etc. & 37,377 & 36,604 & 38,059 \\
\hline Transport and communications & 77,583 & 45,883 & 60,586 \\
\hline Financial activities & 72,691 & 52,210 & - \\
\hline $\begin{array}{l}\text { Public administration and defense; } \\
\text { social insurance }\end{array}$ & 57,682 & 56,610 & 61,910 \\
\hline Education & 40,556 & 40,014 & 46,949 \\
\hline Health care and social services & 37,194 & 39,764 & 50,242 \\
\hline $\begin{array}{l}\text { Provision of other communal, } \\
\text { social and personal services }\end{array}$ & 36,716 & 35,383 & 42,075 \\
\hline
\end{tabular}

Note. The level of climate discomfort: 1-very strong, 2-severe; 3-extremely severe. 
In general, $93 \%$ of districts in the Republic during 1994-2002 and 55\% of districts during 2003-2015 lived having the PCW 2.5 times lower than the average. This level of the PCW, according to B.T. Velichkovsky [15], is the minimum condition for positive changes in indicators of public health. Considering obviously underestimated values of the SM within the study area, in fact the entire population, with the exception of industrial workers, lived on the edge of starvation.

Based on the results of a number of studies [15] [16] [17], it has long been noted that the low level of life inevitably leads to the formation of chronic stress and an increase in morbidity and mortality. Correlation relationships between the level of the SM and the total population mortality in dynamics were investigated under the conditions of severe and extremely severe discomfort [3]. The resulting close relationship of characteristics showed that one of the main reasons for the worsening of the life quality of the population is the understated subsistence minimum.

The data of migration mobility of the population under different climate discomfort also bear evidence of an extremely unfavorable situation (Figure 3). Against the background of a general migration outflow we highlighted the areas which are located under extremely hard discomfortable conditions with repeated index exceeding, compared to its value in the rest of the country. Its peak periods clearly reflect the worsening of the socio-economic problems.

\section{Conclusions}

All the above-stated shows an important role of natural-climatic factors in the development of the region. At the present stage the living standards of the population of the Republic of Sakha (Yakutia) are inextricably connected with the processes of transformation of the socio-economic system and social guarantees in the region. The welfare of the population of discomfort territories directly depends on public support, which consists in ensuring minimum living standards.

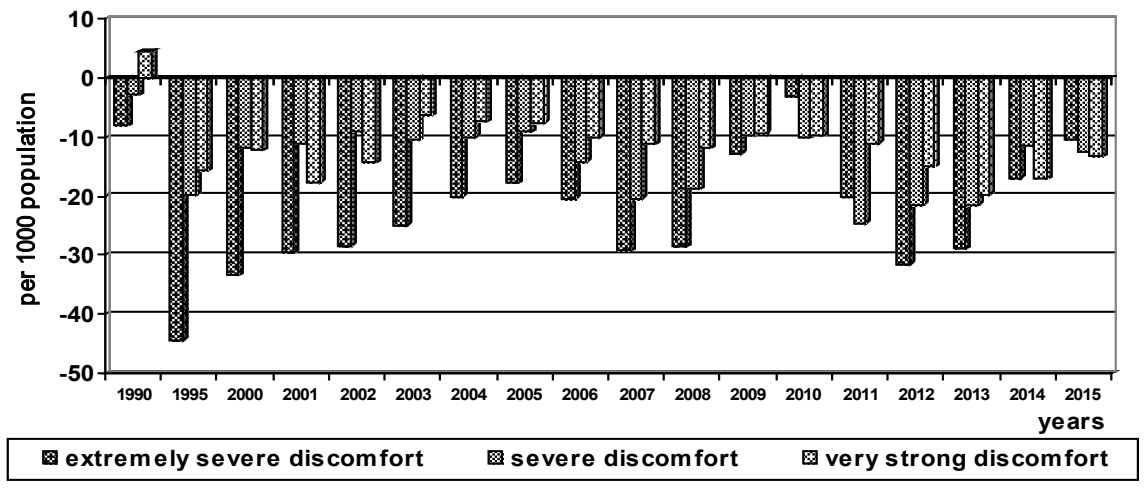

Figure 3. Dynamics of the migration outflow of the population under the conditions of different levels of climate discomfort. Source: Data of the Federal State Statistics Service. http://www.gks.ru; Economy of the districts and towns of the Republic of Sakha (Yakutia) 2010; Economy of the uluses and towns of the Republic of Sakha (Yakutia) 2000 [2] [12] $[13]$. 
At this stage, the intra-differentiation calculating the SM does not correspond to the actual climate severity. This leads to decrease in the level and life quality, and enhance its migration mobility, in spite of the prosperous statistics of PCW. Bringing the level of PM to the minimum physiological needs of people under the conditions of different climate discomfort will contribute to the progressive development of the region.

The abovementioned problems are relevant for the dynamic development of the Arctic areas, where there are often unidirectional amplification of climate discomfort, reduction of social guarantees and remuneration.

\section{References}

[1] Shevyakov, A. (2011) Reorganization of Distribution Relations as a Prerequisite for Socio Economic Development of Russia's Regions. Ekonomika Regiona, 1, 7-14. http://economyofregion.uralces.ru/Data/Issues/ER2011/March_2011/ERMarch2011 7_14.pdf

[2] Data of the Federal State Statistics Service. http://www.gks.ru/dbscripts/munst/munst98/DBInet.cgi

[3] Bashalkhanov, I., Bashalkhanova, L., Veselova, V. and Korytny, L. (2011) Analysis of Social Problems of Life of the Population of Eastern Siberia. By the Example of the Republics of Buryatia and Sakha (Yakutia). SOTsIS, 2, 31-39. http://www.isras.ru/files/File/Socis/2011-2/Bashalhanov.pdf

[4] Federal Law of 03.12.2012 No. 233-FZ "On Amending the Federal Law", "On the Subsistence Minimum in the Russian Federation”. http://base.garant.ru/70271652/

[5] Bashalkhanova, L., Veselova, V. and Korytny, L. (2012) Resource Measurement of Social Conditions of Life of the Population of Eastern Siberia. Akademicheskoe izd-vo "Geo", Novosibirsk, 221.

[6] State Statistics Committee of the Russian Federation (Goskomstat Rossii) (1998) Russian Statistical Yearbook: Statistics Digest. Moscow, 813.

[7] Government Decree of the Republic of Buryatia of 11.03.2016 No. 86. http://www.garant.ru/hotlaw/buryat/703625

[8] Government Decree of the Sakha (Yakutia) Republic of 29.02.2016 No. 45. http://docs.cntd.ru/document/432893733

[9] Government Decree of Krasnoyarsk Krai of 19.01.2016 No. 13. http://www.zakon.krskstate.ru/0/doc/30054

[10] Government Decree of Irkutsk Oblast of 29.01.2016 No. 43. http://irkobl.ru/sites/society/news/197247

[11] Government Decree of Moscow Oblast of 17.03.2016 No. 185/8. http://docs.cntd.ru/document/537990442

[12] Economy of the Districts and Towns of the Republic of Sakha (Yakutia) 1990, 2000-2009 (Statistics Digest) (2010). Sakha (Yakutia) stat, 186.

[13] Economy of the Uluses and Towns of the Republic of Sakha (Yakutia) 1990-1999 (Statistics Digest) (2000). Sakha (Yakutia) stat, 145.

[14] Regions of Russia. Socio-Economic Indicators: Statistics Digest (2015). Rosstat. Moscow, 1266.

http://www.gks.ru/wps/wcm/connect/rosstat_main/rosstat/ru/statistics/publications /catalog/doc_1138623506156

[15] Velichkovsky, B. (2008) Viability of the Nation. A Special Role of Work Motivation 
and Social Stress. Ekologiya cheloveka, 10, 3-8.

https://cyberleninka.ru/article/v/zhiznesposobnost-natsii-osobaya-rol-trudovoy-mo tivatsii-i-sotsialnogo-stressa

[16] Tapilina, V. (2003) Economic Status and Health of a Man. In: Russia, Which We Obtain: Research of the Novosibirsk Economic-Sociological School, Nauka, SB RAS, Novosibirsk, 491-507.

[17] Rimashevskaya, N. (2010) Radical Change of the Negative Trend in the Russian Population Health. Narodonaselenie, 1, 4-18.

https://cyberleninka.ru/article/n/sotsialnaya-politika-sberezheniya-naroda-radikaln oe-izmenenie-negativnogo-trenda-zdorovya-rossiyskogo-naseleniya

Submit or recommend next manuscript to OALib Journal and we will provide best service for you:

- Publication frequency: Monthly

- 9 subject areas of science, technology and medicine

- Fair and rigorous peer-review system

- Fast publication process

- Article promotion in various social networking sites (LinkedIn, Facebook, Twitter, etc.)

- Maximum dissemination of your research work

Submit Your Paper Online: Click Here to Submit

Or Contact service@oalib.com 